2021, Volume 16, ATEE 2020 - Winter Conference. Teacher Education for Promoting WellBeing in School. Suceava, 2020, pages: 319-331|

https://doi.org/10.18662/lumproc/atee2020/21

\section{A Combination of Professional and Personal Qualities in the Choir Conductor}

\section{Liliya NIEMTSOVA ${ }^{1}$}

${ }^{1}$ Candidate of Art History, Assistant at the Music Departments of the Faculty of Pedagogy, Psychology and Social Work Yuriy Fedkovych Chernivtsi National University (Chernivtsi, Ukraine)

l.niemtsova@,chnu.edu.ua
Abstract: The article outlines the problem of combining professional and personal qualities in the choir conductor. Research gaps in the profession of choir conductor are outlined. We established that the art of conducting, and choral performance as its component, currently requires professionally trained personnel, who have an active life position and are able to provide a creative approach to choral singing. It was found that conducting should be interpreted as a creative process characterized by a step-by-step structure and a combination of analysis and comprehension of the choral score, its artistic interpretation, which allows embodying the formed musical image in the real choral sound.

It was found that the conductor's professional qualities are based on the conductor's individual style, or his "creative method". It is established that the emotional sphere of the conductor is the result of a combination of qualities that will allow the conductor and the choir to demonstrate a bright and convincing revelation of the originality of texture, expressive timbre colors of numerous choral scores, and a rich palette of nuances.

Keywords: conductor, choir, art, personal qualities, professional qualities, singers, competence, competencies, creativity, ability, activity

How to cite: Niemtsova, L. (2021). A Combination of Professional and Personal Qualities in the Choir Conductor. In O. Clipa (vol. ed.), Lumen Proceedings: Vol. 16. ATEE 2020 Winter Conference. Teacher Education for Promoting Well-Being in School. Suceava, 2020 (pp. 319-331). Iasi, Romania: LUMEN Publishing House.

https://doi.org/10.18662/lumproc/atee2020/21 


\section{Introduction}

\subsection{Topicality and rationale}

Diversification of the choir's artistic language in the 21st century, the use of new methods of achieving harmony and rhythm in this area are the factors that contribute to improving the artistic and technical skills of choral singers, improving their hearing, quality of taste in terms of music perception, etc. It happens sometimes that modern works are significantly ahead of the capabilities of the most perfect performing arts. These factors pose new challenges to modern choir conductors.

An integral feature of a modern choir conductor should be deep knowledge, extensive erudition in a variety of fields, such as psychology, pedagogy, history of music and vocals, solfeggio, etc. The professional erudition is appropriately perceived by the choir singers, because the artists must trust the conductor, recognize his professionalism and the rightness of creative attitudes, as well as intentions and plans. In order for a conductor to be able to convince singers, he must have a set of knowledge, skills and abilities that exceed the relevant competencies of ordinary artists. In this way, the conductor-choirmaster will assert his authority.

The high professionalism of the choir conductor in the modern world is determined by his creative activity and a set of positive personal qualities. The current high-tech time is characterized by increased demands on the intensity of the conductor-choirmaster, his constant work on himself. The conductor's ability to uniquely interpret the artistic idea of the work, to constantly improvise and bring innovations to this process is important.

The review of the professional literature shows that the process of forming and improving the professional qualities of a choir conductor is directly related to two vectors - the conductor-performer, as well as the choirmaster ones. The latter involves the formation of methods of rehearsal work with the choir, as well as appropriate pedagogical methods and skills. Therefore, it is very important to avoid "distortions" in one direction or another, as well as to pay due attention to the conductor's personal qualities. 


\subsection{Review of recent research and publications}

Almost all scholars who professionally dealt with this issue (Bondarenko, 2013; Doroniuk, 2004; Erzhemsky, 1993; Hrum-Hrzhimailo, 1973; Judin, 1977; Kofman, 1986; 2009; Kozyr, 2008; Makarenko, 2005; Mikhailov, 1966; Pliachenko, 2010; Rozhok, 1994; Sapozhnikova, 2007; Smirnova, 2003; Sohor, 1965; Zhivov, 1987;) are convinced that improving the quality of training and education of choral conductors requires an organic ratio of all components of professional training.

Scholars consider the professional qualities of a conductor without separating them from personal ones. In many cases, they are arranged in unifiedgroups. In particular, V. Rozhok and other scholars propose the following division (Rozhok, 1994):

Table 1. The professional qualities of a conductor (Rozhok, 1994)

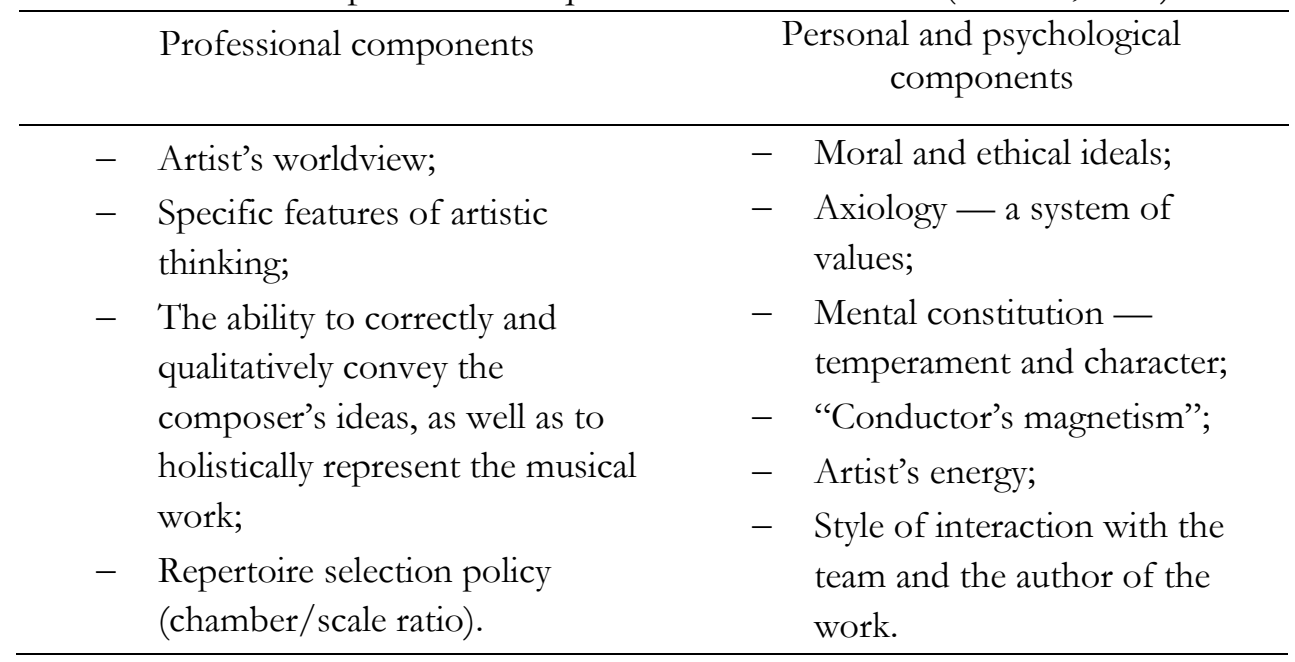

\section{Aims of research}

The objective of this publication is to systematize and generalize information about the combination of qualities of a specialist and a person in the profession of choir conductor.

The object of research of this article is the profession of choir conductor. 
The subject of research is a set of professional and personal qualities of a choir conductor.

\section{Research methods}

The methodology of this study involves the use of system analysis. According to this method, the object is studied not in isolation from its environment and system, but within its context. It is a system analysis that involves understanding the studied processes through the prism of a certain musicological triad "composer - performer - listener". However, the listener in this system is mandatory, because the vocal art cannot be comprehensively understood without taking into account its effect on the audience.

\section{Results}

The choir conducting profession has significant prospects for study and scientific understanding. At the same time, the psychology of the choir conductor's work occupies an important place among the priority areas for understanding this profession. The study of the following components is efficient: the conditions of origin of this profession, the history of development and, finally, the professional and psychological characteristics of the conductor.

It is known that there has been an active theoretical study of the principles of conducting, but it lags behind the real practice of choral art. Particular material in the field of musicology, which concerns, on the one hand, conductor orchestra, and on the other - conductor choir performance, requires appropriately developed theoretical and methodological principles (Bondarenko, 2013). The conducting profession has a significant number of research gaps, in particular in the areas of identifying the essence, general and specific patterns of the nature of the art of conducting, revelation of specific features of the conductor's work with the choir. In addition, the socio-cultural and psychological circumstances of the conductor's effective work with the choir need to be studied. 
The conductor's manual technique in the context of its appropriate aesthetic and psychological understanding is an important area of relevant professional research (Doroniuk, 2004). Therefore, scholars should pay tribute to the already conducted theoretical and practical studies, and continue to search for answers to the question: how the conductor exercises the artistic influence on artists and the public. In this context, a dilemma arises: in fact, what is the conductor's profession is - art or craft, and if it is only a craft, why it has such a powerful impact on the psyche and emotions of each person. It probably depends on the quality of the manual conducting technique, which is formed by the professional and personal qualities of the conductor.

Conducting art, and choral performance as its component, requires professionally trained staff who have an active position in life and are able to provide a creative approach to choral singing.

According to some authors, the art of conducting and performance should be considered in the so-called "Pure" form, which is usually a conditional action, because there is no social vacuum in the world of art (Kozyr, 2008).

\section{Professional qualities of the conductor}

Professional qualities of a choir conductor provide that conducting should be understood as a creative process characterized by a step-by-step structure, as well as combination of analysis and comprehension of the choir score, its artistic interpretation, which allows embodying the formed musical image in the real choral sound. Conducting can be carried out during both rehearsal and concert activities.

It is known that the profession of a conductor provides for his special professional qualities, professional suitability. The generally accepted psychophysiological and characterological properties of the conductor include: muscular activity and plasticity of expressiveness of movements, purposefulness, independence, stability and persistence. This list should usually include calmness as a special type of balance.

That is why the successful professional activity of the choir conductors directly depends on the availability of specific information about 
the necessary professional skills and knowledge that ensure the conductor's effectiveness. According to some authors, the basis of these professional qualities is the conductor's individual style, or his "creative method". In particular, O. Sohor correlates style and method through the expression of formal and content concepts, while the creative method is manifested through style, and content is manifested through the form (Sohor, 1965, p. 28).

These authors argue: if the method is essentially «a general basis, approach to the material of life, a means of creative cognition, generalization and reflection of reality in the system of a particular worldview" (Mihajlov, 1966 , p. 21), the style forms the individual manifestations of the method. In this way, the relationship between the concepts of "creative method" and "style" should be understood as a comparison of general and partial, respectively.

According to the professional classification of conductors by $\mathrm{T}$. Grum-Grzhimailo, there are several pairs of antagonistic types of performance: emotional type — intellectual ("singer-lyricist"/"graphic designer”); verbal type, i.e. speechless; artistic type, i.e. pedagogical (HrumHrzhimailo, 1973, p. 34).

If we take into account the well-known classification of people by temperament (sanguine, choleric, melancholic, phlegmatic), we can classify the representatives of the conductor's "shop" accordingly. These types can be as follows:

- intellectual type (in which the depth and insight of performance is accompanied by limited emotionality, which does not provide for spontaneity, as well as thoughtful improvisation and accurate, logical and reasoned subjectivism);

- emotional (predominance of emotions, accompanied by artistic freedom, the will of subjective feelings, a high level of intuitive, spontaneous, impulsive components during the performance);

- rationalist type (which is based on the exact estimate and objectivity of the interpretation of the work, while the logic of the artist's plan involves "construction of monolithic structures from parts") (Zhivov, pp. 90-91). 
There are other types of classifications of professional qualities, in particular G. Judin proposed one of these classifications (quite metaphorical). According to him, conductors can be:

- "those who are dominated by an emotional principle that ensures the introduction of elements of improvisation" - "it is enough for them to strike a match to spark off the orchestra and lead it even without rehearsals" (this is usually an emotional type);

- "those who, after thinking and feeling everything in the score, do not deviate from the concept, but ensure performance of the culmination with the accuracy of a mathematician instead, repeating the interpretation and not making changes to it" (this is a rationalist type);

- "those who create the future concert performance gradually, floor by floor, like a beautiful house" (it is rather an intellectual type) (Judin, 1977, p. 29).

\section{Personal qualities}

Personal qualities of the conductor should be divided into the following subgroups:

- the qualities necessary for the conductor as the organizer: understanding of music and singing, skills, knowledge and abilities of the manager;

- the qualities of the conductor as a creative person: emotional and volitional, psychological and artistic qualities, as well as the comprehensive development of personality (erudition, etc.) (Sapozhnykova, 2007).

Of course, the mechanisms of work of the conductor and the creative team of the choir (orchestra) are not new to art history (as well as related research subjects, including pedagogical psychology, etc.). In particular, R. Kofman studied them, who believed that there are two groups of contradictions that relate to the peculiarities of the conductor's interaction with the choir. First, it is the internal contradictions that are inherent in the character of the conductor, in particular in the combination of his emotional and rational principles, as well as in his confidence in the correctness of his actions. Second, these are external contradictions that are 
manifested in the relationship during rehearsals and concerts (Kofman, 1986).

Makarenko G. believed that in order to exercise his influence on the team the conductor should act as a translator of his own author's concept of the work being performed, as well as involve other performers in the realization of this concept. The channels of this influence are conditional rational sphere (which involves working with consciousness through the use of language), as well as paralinguistic sphere (which involves influencing the subconscious segment through the use of the conductor's charisma and magnetism, as well as willpower) (Makarenko, 2005, p. 243).

Yerzhemsky G., considering the components of the interaction between the conductor and the creative team, identifies the following 3 components:

1) the system of self-organization and self-management by the conductor;

2) the system of own (internal) self-regulation of the choir;

3) the system of communication and interaction between the conductor and the choir (Erzhemsky, 1993, p. 11).

Based on these 3 components, the conductor uses his existing arsenal of skills to establish psychological contacts and communications, shows the ability to attract attention, ensure effective communication, to adjust the actions of the choir. His leadership in the creative team should be based on the "energy of management".

The psychological factor of the relationship between the conductor on the one hand and the performers on the other is important. This is necessary because the process of conducting involves direct communication with individual performers who realize the conductor's idea. It is worth mentioning the statement of $\mathrm{N}$. Rakhlin, who wished the conductor to always remember that "not instruments - oboes, trumpets, flutes, violins -but living people with different characters, tastes, technical skills" are in front of him (Rozhok, 1994, p. 97). This statement should be complemented by the R. Coffman's view. According to his vision, the most difficult component in the conductor's profession is his relationship with the team, because "the compass in choosing a solution can only be a combination of 
friendly attitude to people who have a sense of responsibility to the composer" (Kofman, 2009, p. 36).

Returning to the emotional sphere of the conductor, we should note that it is the result of a combination of qualities that will allow the conductor and the choir to demonstrate a bright and convincing revelation of the originality of texture, expressive timbre colours of numerous choral scores, and a rich palette of nuances.

This requires, in particular, strong-willed personal qualities that contribute to the conductor's work in the course of his joint creative work with the choir, during which he manages the tempo-rhythm, as well as its modifications. In this sense it is necessary to distinguish positive and restraining factors influencing evolution of the conductor's volitional qualities:

-Stimulating factors: decisiveness, persistence, endurance, purposefulness, independence, organization, initiative, discipline, selfcontrol, as well as diligence, which must be shown at all times — in practices and rehearsals with the choir;

-Restraining factors: inability to distribute time, allocating the necessary time for training, improper patience and diligence in the study of choral scores, lack of independence and disorganization in performing certain assignments, improper attitude to the profession and "colleagues in the shop" in the course of mastering certain subjects, domestic and family problems, negative attitudes/conflicts in the team.

So, in addition to the actual professional skills, the conductor usually has certain qualities, i.e. personal traits that will help him in his work. Leadership qualities and managerial behaviour provide a certain style of pedagogical management. Depending on the desire for leadership, his styles can be divided into soft, hard and partner. This thesis was developed by domestic authors. According to V. Rozhok, speaking about the type of conductor's work with artists, that is "style of communication with the team", one should distinguish between authoritarian and democratic styles (the latter is also called tolerant) (Rozhok, 1994). 
Since the assessment of these styles has been given many times in the professional literature on management, it is advisable to briefly describe them in terms of the activities of the choir conductor.

The soft management style allows the choir director to reduce his activities to ensuring the fulfilment of professional and special tasks only. As the education of the team is almost absent, the singers gain considerable freedom. As a rule, this management style is used by the conductor in teams that have been working for a long time, consisting of singers who have a proper education and great creative potential.

Autocratic style involves excessive centralization of power - the conductor tries to maximize management, focusing even on the little things (so-called "micromanagement"). Given the above, this style can be effective in stressful situations, but in the case of constant use it deprives performers of initiative and does not contribute to the revelation of their creativity.

Finally, the partnership style contributes to the formation of a proper climate in the choir. With this style, the conductor shows respect for the personality of the singers and, as far as possible and appropriate, involves them in management. Each singer of the choir receives his recognition and the most adequate assessment of his successes or failures. Of course, a leader who adheres to a partner style should be appropriately demanding of the choir.

In view of all the above, the competence of a choral conductor is formed and maintained through a number of functional features of the nature of the profession. Since the basis of the conductor's work is its versatility, his professional qualities should also consist of several components:

- personal development;

- ability to independently ensure the performance of professional work;

- professional music training, general and musical culture.

In general, the choir conductor must not only know outstanding musical data, but know all the intricacies of his work, he must also combine the qualities of a psychologist, organizer, teacher, as well as be familiar with the professions of music director, singer and actor. 


\section{Conclusions}

The analysis of the subject matter of this article allows us to state the following:

-The conductor's profession, despite the already published significant number of works (monographs, dissertations, publications, methodological/pedagogical developments), still leaves ample space for further study. In particular, the specific features of the profession need to be substantiated. The conductor's ability to manage the choir and orchestra depends on these features, as well as the ability to realize his own "charge" with the theory of musical knowledge and skills in the practice of managing artists. This should include a set of emotional and volitional qualities of the conductor, which should be the basis of his influence on the team. Of course, neither professional nor personal qualities can exist separately from creative talent.

- Professional features of choir conductors include: the specifics of the conductor's thinking and emotions, professional self-esteem — at different levels and in different dynamics of development. This is where the role of the conductor's practice of working with the choir is important, in particular by organizing an internship in the choir as an assistant conductor or second conductor. An additional means of developing professionally significant qualities are competitive events, where a novice conductor can both test his potential (as well as the adequacy of its assessment) and consider the relevant experience of his colleagues and senior mentors. As for personal qualities, no competition can fully test them, but psychologists can give a proper assessment.

-Theory and practice show the close interrelation of significant personal qualities of choir conductors both among themselves and with professional/professional features. The more dynamically developing and the more technological the art of conducting, the more positively it provides the construction of forms of works performed by the choir. In fact, the skill of the conductor ensures the identification of ideological and artistic content and the culmination of a particular work. 
This topic undoubtedly has a number of promising areas of research, in particular the study of foreign, including Eastern European, experience of pedagogical activities for the formation of professional skills of the choir conductor and the development of his positive personal qualities.

\section{References}

Bondarenko, A. V. (2013). Formuvannia dyryhentskykh pryiomiv u maibutnikh uchyteliv muzyky $\mathrm{v}$ protsesi profesiinoi pidhotovky [Formation of conducting techniques in future music teachers in the process of professional training]. Naukovi zapysky Ternopilskoho natsionalnobo universytetu imeni Volodymyra Hnatinka. Seriia: Pedabobika [Scientific notes of Ternopil National University named after Volodymyr Hnatyuk. Series: Pedagogy], (4), 127-131.

Doroniuk, V. D. (2004). Kurs tekhnika dyryhuvannia dlia vykladachiv $i$ studentiv vyshchykh navchalnykh zakladiv $i$ vchyteliv shkil riznykh typiv [Conducting course for teachers and students of higher educational institutions and teachers of different types of schools]. Ivano-Frankivsk.

Erzhemsky, G. L. (1993). Zakonomernosti i paradoksy dirizhirovanija [Regularities and paradoxes of conducting]. Sankt-Peterburg: Fort.

Hrum-Hrzhimailo, T.N. (1973). Ob iskusstve dirizhera [On the art of the conductor]. Knowledge.

Judin, G. J. (1977). Za gran'ju proshlyh dnej: Iz vospominanij dirizhera [Beyond the past days: From the memories of the conductor]. Music

Kofman, R. I. (1986). Vykhovannia dyryhenta: psykbolobichni osoblyvosti [Vikhovannya of the conductor: psychological specialties.]. Muzychna Ukraina.

Kofman, R. I. (2009). Diriz̧er i orkestr ili sto nenuzhnyh sovetov molodym dirizheram [Conductor and orchestra, or a hundred unnecessary tips for young conductors.]. Abris

Kozyr, A. V. (2008). Profesiina maisternist uchyteliv musylky: teoriia i praktyka formwvannia v systemi bahatorivnevoi osvity: monohrafiia [Professional skill of music teachers: theory and practice of formation in the system of multilevel education: monograph.]. NPU imeni M. Drahomanova.

Makarenko, H. H. (2005). Tvorchist dyryhenta: Estetyko-mystetstvoznavchi vyminy [Creativity of the conductor: Aesthetic and art dimensions]. Fakt.

Mihajlov, M. K. (1966). O ponjatii stilja $v$ muzyke [About the concept of style in music]. Voprosy teorii i jestetiki musyki [Questions of theory and aesthetics of music], (4), 15-26.

Pliachenko, T. M. (2010). Pidhotovka maibutnoho vchytelia musyky do roboty z. uchnivskymy orkestramy ta instrumentalnymy ansambliamy: monobrafia [Preparation of a 
Maybut music reader to robotics with academic orchestras and instrumental ensembles: monograph]. Imeks - LTD

Rozhok, V. I. (1994). Stefan Turchak: dyryhent, mytets, bromadianyn [Stefan Turchak: conductor, artist, citizen]. Kharkiv City Printing House.

Sapozhnikova, L. D. (2007). Artistizm lichnosti kak vazhnyj komponent v strukture professional'no znachimyh kachestv dirizhera [Personality artistry as an important component in the structure of professionally significant qualities of a conductor]. Gedevanouskie chtenija [Gedevan readings]. Moscow, 41-47.

Smirnova, T. A. (2003). Teoretychni ta metodychni zasady dyryhentsko-khorovoi osvity u vyshchykh navchalnykh zakladakh : dys. ... d-ra ped. nauk: 13.00.04. [Theoretical and methodical bases of conducting and choral education in higher educational institutions: dis. Dr. Ped. Science: 13.00.04.]. Kyiv: Institute of Pedagogy and Psychology of Vocational Eduction of the Academy of Pedagogical Sciences of Ukraine.

Sohor, A. (1965). Stil', metod, napravlenie (k opredeleniju ponjatij) [Style, method, direction (to the definition of concepts)]. Voprosy teorii $i$ jestetiki musyki [Questions of music theory and aesthetics], (4), 3-30.

Zhivov, V. L. (1987). Ispolnitel'skij analiz, horovogo proizvedenija [Performing analysis of a choral work]. Muzyka. 